\title{
Nodular Fasciitis of the Breast Previously Misdiagnosed as Breast Carcinoma
}

\author{
Volkan Ozben ${ }^{\mathrm{a}}$ Fatih Aydogan ${ }^{\mathrm{a}}$ Fatih Can Karaca ${ }^{\mathrm{a}}$ Sennur Ilvan ${ }^{\mathrm{b}}$ Cihan Uras $^{\mathrm{a}}$ \\ ${ }^{\text {a }}$ Department of General Surgery, \\ ${ }^{\mathrm{b}}$ Department of Pathology, Cerrahpasa Medical School, Istanbul University, Turkey
}

\section{Key Words}

Nodular fasciitis · Breast · Pathology

\section{Summary}

Background: Nodular fasciitis of the breast is a rare benign pathology that can mimic breast cancer clinically, radiologically, and histopathologically. Case Report: An 18-year-old female patient had first visited a physician in a different center with the complaint of a lump in her left breast. Breast examination had revealed a palpable mass located in the left upper outer quadrant. Ultrasonography had demonstrated a hypo-echoic lesion. Excisional biopsy of the lump had been performed and histopathologic examination misdiagnosed this lump as a mesenchymal tumor. The patient was then referred to our clinic for further investigations. Pathologic revision was performed and the diagnosis of nodular fasciitis of the breast was established. Conclusion: Awareness of this rare clinical entity, nodular fasciitis, in the breast eliminates the misdiagnosis of breast cancer.

\section{Introduction}

Nodular fasciitis (NF) of the breast is a benign pseudosarcomatous proliferative lesion that may develop very rarely and is characterised by sudden appearance and growth. It can be mistaken for a breast carcinoma due to its vague clinical, radiological, and histological features [1]. We report a case of NF of the breast previously misdiagnosed as breast carcinoma.

\section{Case Report}

An 18-year-old, previously healthy female patient had been seen by a physician in a different hospital with the complaint of a painless lump in the upper outer area of her left breast. The breast examination had revealed a palpable mass located in the 1 o'clock position of her left breast,

\author{
Schlüsselwörter \\ Noduläre fasciitis · Mamma · Pathologie
}

\section{Zusammenfassung}

Hintergrund: Die noduläre Fasciitis ist eine seltene benigne Erkrankung der Mamma, die klinisch, radiologisch und histopathologisch Brustkrebs imitieren kann. Fallbericht: Wir stellen den Fall einer 18 Jahre alten Patientin vor, die wegen einer Geschwulst in ihrer linken Brust in einer anderen Klinik vorstellig wurde. Die dortige Untersuchung ergab einen palpablen Knoten im linken oberen äußeren Quadranten. Die Sonographie zeigte eine hypodense Raumforderung. Es folgte eine Exzisionsbiopsie mit einer histopathologischen Untersuchung, die diesen Knoten als mesenchymalen Tumor deutete. Zur weiteren Untersuchung wurde die Patientin in unsere Klinik überwiesen. Nach Überprüfung der histopathologischen Diagnose musste diese revidiert werden. Es zeigte sich das Bild einer nodulären Fasciitis und die Einweisungsdiagnose Tumor wurde verworfen. Schlussfolgerung: Das Wissen um die Möglichkeit dieser seltenen Erkrankung, noduläre Fasciitis, könnte die Fehldiagnose Mammakarzinom vermeiden.

but no nipple discharge nor nipple retraction, and no axillary nor supraclavicular lymphadenopathy. Ultrasonography had shown a superficially located hypo-echoic lesion measuring $8 \times 5 \mathrm{~mm}$ in diameter. Excisional biopsy had been performed under local anesthesia and the diagnosis of a mesenchymal tumor with spindle cells had been made on histopathologic examination. The patient was then referred to our clinic for further evaluation. Physical examination was not contributory apart from a surgical scar in her left breast. The rapid growth of this lesion in this young female patient with no past medical and family history led us to a clinical impression of a benign pathology. Therefore, the stained paraffin sections were revised and the final diagnosis of NF was made.

\section{Discussion}

NF, which was first described by Konwaler et al. [2], is a benign proliferation of myofibroblasts characterized by its com-

\begin{tabular}{ll}
\hline KARGER & @ 2009 S. Karger GmbH, Freiburg \\
Fax +497614520714 & Accessible online at: \\
Information@Karger.de & www.karger.com/brc \\
www.karger.com &
\end{tabular}




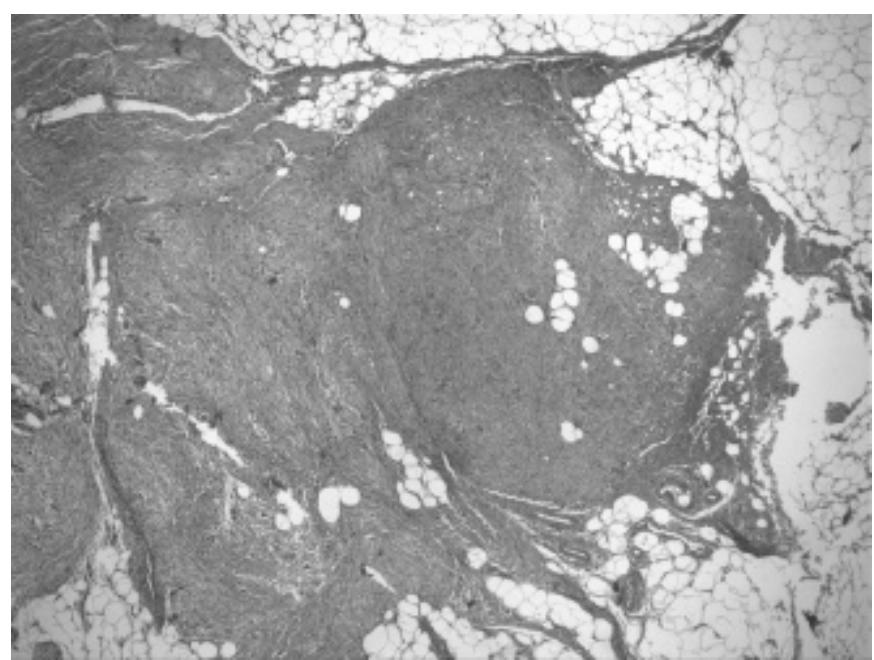

Fig. 1. Bundles of spindle-shaped cells with blunt cytological features in nodular fasciitis of the breast (hematoxylin and eosin, $\times 40$ ).

mon location in the subcutaneous tissues of the upper extremities, the head and neck [3]. The most characteristic feature of NF is a single, rapidly growing mass $[4,5]$. It is reported to occur in young adults between 20 and 35 years of age. Males and females are equally affected.

According to Squillaci et al. [7], NF has been rarely described in the female breast, with fewer than 15 histologically proven cases reported in the literature. The etiopathogenesis of NF is unknown. However, it is believed that local injury may trigger the fibroblastic proliferation $[3,6-8]$. The history of trauma was elicited in no more than $10-15 \%$ of patients [4]. There was also no history of trauma in our case.

NF of the breast forms a hard mass and appears to be irregular in shape on physical examination. Mammography reveals an irregular, often spiculated lesion and ultrasonography detects an infiltrative mass without a capsule $[1,3,6]$. These suspicious imaging features of NF are alarming enough for a breast carcinoma $[1,4,6]$. A literature review of 11 patients with NF reported by Brown and Carty [4] showed that mammography findings were suspicious in 2 patients and consistent with malignancy in 4 patients. In this case, mammography had not been performed prior to surgery due to her young age, and ultrasonographic examination showed a superficially located hypo-echoic lesion. Because NF has no unique radiological appearance [1, 8], the exact diagnosis can only be made on histopathologic examination $[1,7,8]$. Neither fine-needle aspiration cytology nor core needle biopsy easily diagnoses NF because it is difficult to obtain representative cells to make a correct diagnosis by these techniques $[1,7]$. The diagnosis usually requires the histopathologic examination of an excisional biopsy $[1,3,4,6]$.

The key cytologic features for diagnosis are plump, immature fibroblast-like spindle cells in a myxoid material, chronic inflammatory cells, capillary proliferation, and vascular channels with extravasated red blood cells [4-7]. In this patient, proliferation of spindle-shaped to plump fibroblastic cells in collagenous stroma was seen. These cells had oval and palestaining nuclei hardly varying in size and shape and without atypical mitotic features (fig. 1).

The differential diagnosis of NF includes fibromatosis, myofibroblastoma, granulation tissue, radial scars, phyllodes tumor, sarcomatoid carcinoma, primary sarcoma, and metaplastic carcinoma $[1,6,7]$. NF can be differentiated from these entities on the basis of cellularity, nuclear pleomorphism, collagen content, and growth pattern [7].

For the treatment of NF, either conservative management or excisional biopsy can be chosen. A conservative approach is appropriate if the lesion has a typical clinical appearance, with the core biopsy consistent with NF [4]. Spontaneous regression has been observed $[4,6]$. If these criteria are not met, excisional biopsy is the effective treatment, and no further treatment is necessary $[3,7]$. Recurrence following surgical excision is rare $[4,7,9]$. We recommend conservative management provided that confirmation of NF is made clinically and histologically. Otherwise, surgical excision should be performed in equivocal cases.

In summary, NF of the breast is a rare lesion that mimics breast cancer clinically, radiologically, and histopathologically. Correct diagnosis can only be made on histopathologic examination. The pathologist should also be aware of the patient presentation in order not to misdiagnose this benign entity.

\section{Conflict of Interest}

The authors have no financial interest in the products presented in this work.

\section{References}

1 Dahlstrom J, Buckingham J, Bell S, Jain S: Nodular fasciitis of the breast simulating breast cancer on imaging. Australas Radiol 2001;45:67-70.

2 Konwaler BE, Keasbey L, Kaplan L: Subcutaneous pseudosarcomatous fibromatosis (fasciitis). Report of 8 cases. Am J Clin Pathol 1955;25:241-252.

3 Hayashi H, Nishikawa M, Watanabe R, Sawaki M, Kobayashi H, Shibata A, Kikumori T, Nagasaka T, Imai T: Nodular fasciitis of the breast. Breast Cancer 2007;14:337-339.
4 Brown V, Carty NJ: A case of nodular fascitis of the breast and review of the literature. Breast 2005;14: 384-387.

5 Porter GJ, Evans AJ, Lee AH, Hamilton LJ, James JJ: Unusual benign breast lesions. Clin Radiol 2006;61:562-569.

6 Tulbah A, Baslaim M, Sorbris R, Al-Malik O, AlDayel F: Nodular fasciitis of the breast: a case report. Breast J 2003;9:223-225.
7 Squillaci S, Tallarigo F, Patarino R, Bisceglia M: Nodular fasciitis of the male breast: a case report. Int J Surg Pathol 2007;15:69-72.

8 Polat P, Kantarci M, Alper F, Gursan N, Suma S, Okur A: Nodular fasciitis of the breast and knee in the same patient. AJR Am J Roentgenol 2002;178: 1426-1428.

9 Batsakis JG, El-Naggar AK: Pseudosarcomatous proliferative lesions of soft tissues. Ann Otol Rhinol Laryngol 1994;103:578-582. 